\title{
RESPON KONSENTRASI TIENS GOLDEN HARVEST TERHADAP PERTUMBUHAN DAN PRODUKSI KENTANG (Solanum tuberossum L) DENGAN MENGGUNAKAN UKURAN BENIH G3 YANG BERBEDA
}

\author{
Sumatera Tarigan ${ }^{1)}$ Meriksa Sembiring ${ }^{2)}$ Riduan Sembiring ${ }^{3)}$ \\ ${ }^{1) 2) 3)}$ Dosen Fakultas Pertanian Universitas Quality \\ Email : sumatera.tarigan60@gmail.com
}

\begin{abstract}
Abstrak
Penelitian ini bertujuan untuk mengetahui pengaruh jumlah umbi/kg bibit dan dosis pupuk cair hayati terhadap pertumbuhan dan produksi tanaman kentang. Penelitian dilaksanakan di Kebun Percobaan Universitas Quality diBerastagi Kabupaten Karo berada $+2140 \mathrm{~m}$ dpl yang dilaksanakan dari bulan bulan Juni 2017 - September 2017. Penelitian ini menggunakan Rancangan Acak Kelompok Faktorial dengan dua faktor perlakuan. Faktor pertama adalah ukuran umbi bibit dengan empat taraf yaitu : 7 umbi/kg (P1); 14 umbi/kg (P2) dan 21 umbi/kg (P3), dan faktor kedua adalah dosis pupuk Cair Hayati dengan empat taraf yaitu : $0.0 \mathrm{ml} / 1$ air (Ho); $0.2 \mathrm{ml} / 1$ air (H1); $0.4 \mathrm{ml} / 1$ air (H2); $0.8 \mathrm{ml} / \mathrm{l}$ air (H3).

Hasil penelitian menunjukkan bahwa Perlakuan ukuran umbi sebagai bibit berpengaruh nyata terhadap jumlah umbi/sampel produksi/sampel, produksi/plot, Tetapi tidak berbeda nyata terhadap tinggi tanaman, jumlah cabang. Perlakuan dosis pupuk cair hayati berpengaruh nyata terhadap tinggi tanaman, jumlah umbi/sampel, produksi/sampel, produksi/plot.Tetapi tidak nyata terhadap jumlah cabang. Interaksi antara kedua factor perlakuan tidak berpengaruh yang nyata terhadap semua parameter yang diamati sepanjang penelitian.
\end{abstract}

Kata kunci: respon, konsentrasi, pertumbuhan, produksi, kentang

Abstract

This study aims to determine the effect of the number of tubers $/ \mathrm{kg}$ of seeds and the dose of biological liquid fertilizer on the growth and production of potato plants. The research was carried out at the Quality University Experimental Garden in Karo District at +2140 m asl which was conducted from June 2017 September 2017. This study used Factorial Randomized Group Design with two treatment factors. The first factor is the size of seed bulbs with four levels, namely: 7 tubers / $\mathrm{kg}(\mathrm{P} 1)$; 14 tubers / $\mathrm{kg}(\mathrm{P} 2)$ and 21 tubers / $\mathrm{kg}(\mathrm{P} 3)$, and the second factor is the liquid fertilizer dosage with four levels: $0.0 \mathrm{ml} / 1$ water (Ho); $0.2 \mathrm{ml} / 1$ water $(\mathrm{H} 1) ; 0.4 \mathrm{ml} / 1$ water $(\mathrm{H} 2) ; 0.8 \mathrm{ml} / 1$ water $(\mathrm{H} 3)$.

The results showed that the treatment of tuber size as seeds significantly affected the number of tubers / samples of production / samples, production / plots, but not significantly different for plant height, number of branches. The treatment of biological liquid fertilizer doses significantly affected plant height, tuber / sample number, production / sample, production / plot. But it was not significant for the number of branches. The interaction between the two treatment factors did not significantly affect all parameters observed throughout the study. 
Keywords: response, concentration, growth, production, potatoes

\section{PENDAHULUAN}

Tanaman Kentang merupakan tanaman pangan utama dunia setelah padi, gandum dan jagung, namun di Indonesia, kentang masih dikonsumsi sebagai sayur dan makanan ringan dan belum dijadikan sebagai makanan utama pengganti beras, jagung (makanan utama daerah Madura) dan sagu (makanan utama daerah Maluku). Walaupun demikian,di Indonesa tanaman kentang ini mulai menjamur berbagai jenis makanan "fast food" artinya yang utama terutama di daerah yang beriklim dingin (dataran tinggi). Melihat gaya hidup modern terutama di perkotaan maka umbi kentang yang diolah sedemikian rupa dijadikan berbagai jenis fast food dengan semakin lama semakin popular dan kebutuhan akan kentang makin hari makin terus meningkat. Meningkatnya permintaan umbi kentang oleh konsumen menjadikan pertanian kentang memberi peluang emas bagi peningkatan produksi kentang di Indonesia, baik oleh petani maupun oleh perusahaan swasta (Anonimous, 2006).
Produksi di kebun Percobaan dihasilkan lebih tinggi dibandingkan dengan hasil yang diperoleh oleh petani biasa. Kebun percobaan mampu menghasilkan umbi kentang rata-rata 20 ton /hektar dengan varitas umum, akan tetapi beberapa petani apabila menggunakan bibit unggul yang di impor dan pengelolaan hama penyakit dan pengelolaan tanaman yang intensif mampu menghasilkan sampai 30 ton/ hektar (Hartus, 2001).

Meskipun produksi kentang terus meningkat namun masih sangat rendahdibandingkan dengan negara lain seperti Belanda (36 - 60 ton/ha). Rendahnyaproduktifitas ini adalah akibat pemakaian bibit yang kurang baik, varietasberpotensi redah, teknik bercocock tanam yang kurang baik, keadaan lingkunganyang berbeda serta faktor pemupukan (Asandhi, 1985).

Kelemahan para petani kentang di Indonesia adalah pemborosan biayaproduksi. Petani umumnya hanya menggunakan bibit yang di buat sendiri darihasil panen kentang yang sebelumnya dengan memilih 
umbi yang baik danselanjutnya akan di gunakan sebagai bibit. Teknis budidaya yang dilakukan petanisudah cukup baik, hanya saja mereka masih terlalu boros tentang penggunaan biaya,terutama untuk biaya pembelian dan penggunaan pestisida dan pupuk. Bahkan, biaya tersebutdapat mencapai hampir 50\% dari total biaya produksi. Hal ini untuk mengubah teknik pengelolaan pertanaman yang tepat dan modern seperti memerlukan jumlah dan ukuran umbi yang besar.

Sejak tahun 1980-an sampai sekarang, teknik kultur jaringan sudah berkembang pesat di seluruh penjuru dunia sehingga sulit dipantau pemanfaatan yang nyata dari teknik tersebut. Disamping untuk perbanyakan tanaman, juga di bidang rekayasa genetika untuk perbaikan mutu genetika tanaman pertanian (Zulkarnain,2009).

Pemupukan terutama pupuk organik banyak dipergunakan sebagai pemupukan tanaman kentang. Pada sat ini salah satu jenis pupuk yang mempunyai kualitas yang cukup baik adalah pupuk cair hayati. Penggunaan pupuk ini diharapkan dapat meningkatkan pertumbuhan produksidan kualitas umbi kentang. Kenyataan menunjukkan bahwa pemberian pupuk cair hayati selalu dapat meningkatkan kualitas kentang.Salah satu cara untuk meningkatkan produksi kentang disamping menggunakan pupuk yang cukup dengan penggunaan bibit yang baik dan terbebas dari hama dan penyakit.Penggunaan pupuk sebagai salah satu usaha untuk meningkatkan produksi kentang sudah sangat membudidaya, dan para petani telah menganggap bahwa pupuk dan cara pemupukan sebagai salah satu hal yang tidak dapat dipisahkan dalam kegiatan usaha taninya (Anonim,2007).

Upaya untuk meningkatkan produksi tanaman kentang adalah dengan menggunakan teknologi modern, antara lain pemberian pupuk hayati Tiens Golden Harvest. Tiens Golden Garvest merupakan pupuk dengan bahan aktif mikroba asli Indonesia yang ramah lingkungan. Jadi, pupuk ini tidak mengandung logam berat atau bakteri salmonella. Benih Umbi kentang G3 merupakan benih generasi ketiga dari salah satu hasil kultur jaringan.yang lebih terjamin kemurniannya dan terbebas hama dan penyakit. 
Pupuk cair hayati ini umbi/kg, P2 = 14 umbi/kg, P3 = 21 mempunyai kandungan mikroorganisme yang berfungsi sebagai penghasil enzim selulose yang berguna dalam proses pembusukan bahan organik. Sebagai contoh jenis pupuk cair hayati adalah Tiens Golden Harves adalah yang mengandungi kandungan mikroorganisme.

Adapun tujuan penelitian ini adalah untuk menguji konsentrasi Tiens Golden Harvest terhadap pertumbuhan dan produksi kentang (Solanum tuberosum L) serta untuk menguji pertumbuhan dan produksi tanaman kentang (Solanum tuberosum L) dengan menggunakan ukuran benih umbi G3 yang berbeda.

\section{BAHAN DAN METODE}

Penelitian dilaksanakan di areal kebun percobaan Universitas Quality, BerastagiKabupaten Karo. Sumatera Utara dengan ketinggian tempat $\pm 1200 \mathrm{~m} \mathrm{dpl}$.

\section{Metode}

Penelitian

menggunakan Rancangan Acak Kelompok (RAK) faktorial yang terdiri dari 2 faktor yaitu :Faktor I: Perlakuan ukuran umbi bibit G3 (P) yang terdiri dari 3 taraf yaitu:P1 = 7 umbi/kg,

Faktor II :Konsentrasi Pupuk cair hayati terdiri dari 4 taraf yaitu $: \mathrm{H} 0=0 \mathrm{ml} / \mathrm{l}$ air, $\mathrm{H} 1=0.2 \mathrm{ml} / \mathrm{l}$ air, $\mathrm{H} 2=0.4 \mathrm{ml} / \mathrm{l}$ air, $\mathrm{H} 3=0.8 \mathrm{ml} / \mathrm{l}$ air.

$$
\text { Pelaksanaan Penelitian }
$$

:Persiapan Lahan dengan diolah menggunakan cangkul selanjutnya digemburkan dan dibuat petak dengan ukuran $2 \mathrm{~m}$ x 3,2 $\mathrm{m}$ sebanyak 36 plot. Penanaman menggunakan bibit G3berbagai ukuran dilakukan dengan cara memasukkan bibit ke dalam lubang yang terlebih dahulu sedalam $5 \mathrm{~cm}$ ditugal dan dengan jarak tanam $80 \mathrm{~cm} \mathrm{x} 40 \mathrm{~cm}$.

Pembubunan dilakukan untuk memperkokoh tanaman agar tidak roboh/rebah dan stolon yang muncul di permukaan tanah dapat membentuk umbi yang berwarna hijau. Pada saat tanaman berumur 28-30 HST dan umur 35-40 HST dilakukan kegiatan pembumbunan. Pemupukan hayati Tiens Golden Harvest dilakukan pada saat tanaman itu berumur 7, 14, 20, 30, dan 40 hari setelah tanamsesuai perlakuan. Cara pemberian pupuk ini dengan mencampurkan air terlebih dahulu, dilakukan penemprotkan ke seluruh permukaan tanah sampai merata. 
Parameter yang diamati selama penelitian ini dilakuakan adalah pertumbuhan (tinggi tanaman, jumlahcabang), Jumlah umbi/sampel dan produksi per sampel dan produksi/plot.

\section{HASIL PENELITIAN}

Tinggi Tanaman $(\mathrm{cm})$

Pengamatan tinggi tanaman kentang pada masa pertumbuhan dimulai dari pengamatan 2, 4, 6, 8, 10 dan 12 minggu setelah tanam (mst) dengan data terlihat pada Tabel 1 .

Tabel 1. Rata-rata Tinggi Tanaman Kentang pada 4, 6, 8, 10 dan 12 mst (cm) dari Pengaruh Ukuran Benih G3 dan dosis pupuk cair hayati.

\begin{tabular}{lccccc}
\hline Perlakuan & $4 \mathrm{mst}$ & $6 \mathrm{mst}$ & $8 \mathrm{mst}$ & $10 \mathrm{mst}$ & $12 \mathrm{mst}$ \\
\hline P1 (7 umbi/kg) & $35.57 \mathrm{a}$ & $49.06 \mathrm{a}$ & $60.03 \mathrm{a}$ & $65.76 \mathrm{a}$ & $67.85 \mathrm{a}$ \\
P2 (14 umbi/kg) & $36.79 \mathrm{a}$ & $48.78 \mathrm{a}$ & $58.56 \mathrm{a}$ & $64.91 \mathrm{a}$ & $66.69 \mathrm{a}$ \\
P3 (21 umbi/kg) & $36.57 \mathrm{a}$ & $47.39 \mathrm{a}$ & $57.61 \mathrm{a}$ & $63.37 \mathrm{a}$ & $65.33 \mathrm{a}$
\end{tabular}

\begin{tabular}{llllll}
\hline Ho (Kontrol) & $36.18 \mathrm{a}$ & $47.10 \mathrm{a}$ & $55.97 \mathrm{a}$ & $62.04 \mathrm{~b}$ & $64.10 \mathrm{~b}$ \\
H1 (0.2 ml/L air) & $36.80 \mathrm{a}$ & $47.83 \mathrm{a}$ & $58.02 \mathrm{a}$ & $63.94 \mathrm{~b}$ & $65.78 \mathrm{~b}$ \\
H2 (0.4 ml/L air) & $36.93 \mathrm{a}$ & $48.69 \mathrm{a}$ & $59.05 \mathrm{a}$ & $65.00 \mathrm{ab}$ & $67.09 \mathrm{ab}$ \\
H3 (0.8 ml/L air) & $35.32 \mathrm{a}$ & $50.01 \mathrm{a}$ & $61.88 \mathrm{a}$ & $67.72 \mathrm{a}$ & $69.53 \mathrm{a}$
\end{tabular}

Keterangan :Notasi huruf dan kolom yang sama berbeda tidak nyata taraf $5 \%$.

Pertumbuhan tinggi tanaman kentang yang dilakukan pengamatan sejak umur tanaman 4, 6, 8, 10 dan 12 minggu setelah tanam (mst)
Tabel 1. dari pengaruh ukuran bibit kentang G3 tidak menunjukkan perbedaan yang nyata $(\mathrm{p}<0.05)$. Namun peningkatan terus terlihat 
sampai pada umur 12 mst. Pengamatan 12 mst diperoleh tinggi tanaman paling tinggi diperoleh pada P1 (bibit G3 dengan 7 umbi/kg)ratarata $67.85 \mathrm{~cm}$. Penggunaan konsentrasi pupuk cair hayati memberikan respon yang berbeda nyata pada umur tanaman $10 \mathrm{mst}$ (p $<0.05$ ) sampai 12 mst. Pertumbuhan tanaman kentang jelas terlihat pengaruh pemberian dosis pupuk cair ( $p>0.05$ ) pada 12 mst. Penggunaan pupuk cair hayati $0.8 \mathrm{ml} / \mathrm{l}$ (H3) terlihat tinggi tanaman yang paling tinggi rata-rata $69.53 \mathrm{~cm}$. Berkurangnya pemberian konsentrasi tidak memberikan pengaruh yang nyata $(\mathrm{p}>0.05$ ) pada $0.4 \mathrm{ml} / \mathrm{l}$ air rata-rata tinggi $67.09 \mathrm{~cm}$, akan tetapi penggunaan0.2 $\mathrm{ml} / \mathrm{l}$ air $(\mathrm{H} 1)$ pertumbuhan paling rendah berbanding pemberian pupuk (ratarata $65.78 \mathrm{~cm}$ ) dan dengan tidak berbeda nyata terhadap kontrol (Ho) rata-rata tinggi tanaman $64.10 \mathrm{~cm}$.

$$
\text { Berdasarkan analisa }
$$
pemberian pupuk cair hayati pada 12 mst terlihat bahwa dengan demakin tingginya konsentrasi memberikan tinggi tanaman kentang semakin tinggi berdasarkan regresi linier dengan $\hat{Y}=6.37+64.39 \mathrm{H}$, dengan $r$ $=0.99$ seperti yang terlihat pada Grafik 1.

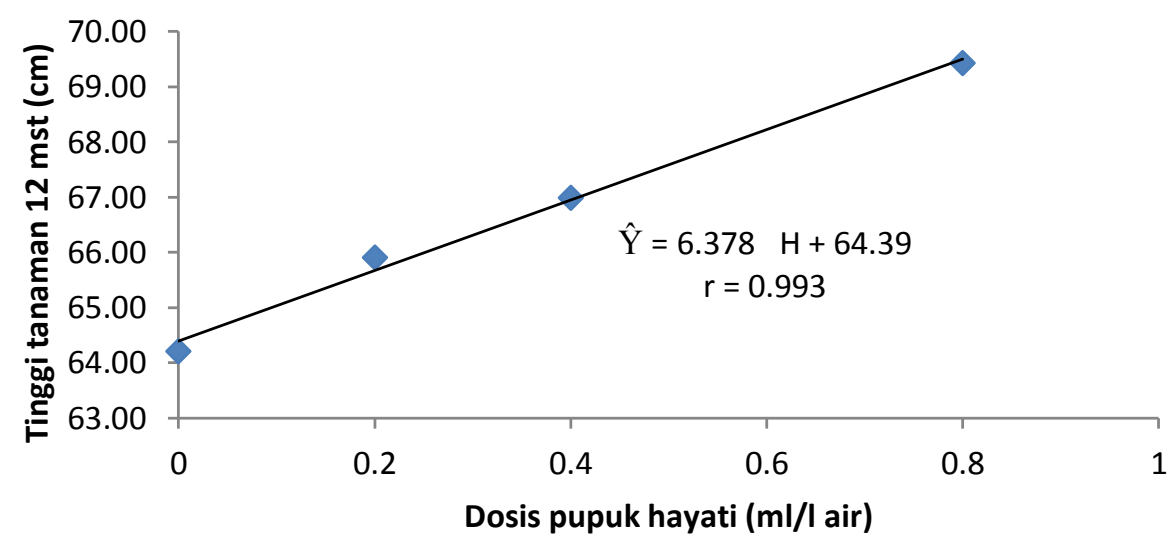

Gambar 1. Hubungan dosis pupuk hayati terhadap perkembangan tinggi tanaman $(\mathrm{cm})$ pada kentang

\section{Jumlah Cabang Utama}

JUmlah cabang utama

dilakukan pada umurtanaman $8 \mathrm{mst}$, dari hasil analisa yang diperoleh dari pengaruh ukuran bibit dan konsentrasi pupuk cair hayati 
yangdiberikan tidak memberikan

pengaruh yang nyata $(\mathrm{p}<$

0.05)dilihat pada Tabel 2.

Tabel 2. Rata-rata jumlah cabang utama tanaman kentang pada umur 8 mst dari

Ukuran bibit dan dosis pupuk cair hayati.

\begin{tabular}{llllll}
\hline Interaksi & P1 & P2 & P3 & Jumlah & Rata-rata \\
\hline Ho & 3.00 & 3.00 & 3.00 & 9.00 & $3.00 \mathrm{a}$ \\
H1 & 3.33 & 2.67 & 3.00 & 9.00 & $3.00 \mathrm{a}$ \\
H2 & 3.33 & 3.00 & 3.00 & 9.33 & $3.11 \mathrm{a}$ \\
H3 & 3.67 & 3.33 & 2.67 & 9.67 & $3.22 \mathrm{a}$ \\
Total & 13.33 & 12.00 & 11.67 & 37.00 & \\
\hline Rata-rata & $3.33 \mathrm{a}$ & $3.00 \mathrm{a}$ & $2.92 \mathrm{a}$ & &
\end{tabular}

Keterangan :Notasi huruf dan kolom yang sama tidak berbeda nyata taraf 5 $\%$.

Jumlah cabang utama pada tanaman kentang dari pengaruk ukuran bibit adalah dengan rata-rata $2.92-3.33$ cabang. Hal ini terlihat dengan ukuran benih 7 umbi/kg (P1) merupakan jumlah cabang paling banyak rata-rata 3.33 cabang sedangkan penggunaan $21 \mathrm{umbi} / \mathrm{kg}$ (P3) merupakan jumlah cabang paling sedikit rata-rata 2.92 cabang.

$$
\text { Pengaruh pemberian }
$$
dosis pupuk cair hayati tidak memberikan pengaruh yang nyata $(\mathrm{p}$ $<$ 0.05) terhadap pembentukan jumlah cabang utama antara $2-4$ cabang. Namun sedikit perbedaan dari pengaruh dosis pupuk yang diberikan.Pemberian pupuk $0.8 \mathrm{ml} / \mathrm{l}$ air (H3) merupakan jumlah cabang yang paling banyak denan rata-rata 3.22 buah cabang.

Produksi kentang (jumlah umbi/sampel, Produksi/sampel dan Produksi/plot)

Hasil perhitungan jumlah umbi/sampel (umbi/knol), setelah dianalisa terdapat adanya perbedaan yang nyata $(\mathrm{p}<0.05)$ dari pengaruh ukuran bibit kantang maupun dosis 
pemberian pupuk cair hayati (Tabel $3)$.

Jumlah umbi yang paling banyak diperoleh dengan menggunakan jenis umbi 7 umbi/kg (P1) dengan rata-rata 14.54 umbi/sampel. Perlakuan ini tidak menunjukkan perbedaan nyata terhadap penggunaan bibit 14 umbi/kg (P2) rata-rata 13.48 umbi, tetapi berbeda nyata terhadap P3 (jumlah paling sedikit rata-rata 11.92 umbi.

Pemakaian pupuk hayati beberapa dosis (Tabel 3) didapati bahwa dosis paling tinggi dengan pupuk cair $0.8 \mathrm{ml} / \mathrm{l}$ air (H3) merupakan penghasilan jumlah umbi per sampel paling banyak dengan rata-rata 15.36 umbi. Perlakuan H3 ini menunjukkan perbedaan tidak nyata terhadap dosis $0.4 \mathrm{ml} / \mathrm{l}$ air $(\mathrm{H} 2)$ rata-rata 13.86 umbi/sampel.

Tabel 3. Rata-rata Produksi (jumlah umbi/sampel (knoll), produksi/sampel dan Produksi/plot) dari pengaruh ukuran benih G3 dan dosis pupuk Cair hayati pada tanaman kentang

\begin{tabular}{|l|r|r|r|}
\hline \multicolumn{1}{|c|}{ Perlakuan } & $\begin{array}{l}\text { Jumlah umbi/ } \\
\text { Sampel (knoll) }\end{array}$ & $\begin{array}{l}\text { Produksi/ } \\
\text { Sampel (g) }\end{array}$ & $\begin{array}{l}\text { Produksi/ } \\
\text { Plot (kg) }\end{array}$ \\
\hline Ukuran Bibit (P) & $14.54 \mathrm{a}$ & $0.58 \mathrm{a}$ & $9.58 \mathrm{a}$ \\
\hline P1(7 umbi/kg) & $13.48 \mathrm{ab}$ & $0.55 \mathrm{ab}$ & $8.08 \mathrm{ab}$ \\
\hline P2 (14 umbi/kg) & $11.92 \mathrm{~b}$ & $0.53 \mathrm{~b}$ & $6.97 \mathrm{~b}$ \\
\hline P3 (21 umbi/kg) & $11.78 \mathrm{c}$ & $0.52 \mathrm{~b}$ & $6.13 \mathrm{c}$ \\
\hline Ho (Kontrol) & $12.25 \mathrm{bc}$ & $0.54 \mathrm{~b}$ & $7.38 \mathrm{bc}$ \\
\hline H1 (0.2 ml/L air) & $13.86 \mathrm{ab}$ & $0.56 \mathrm{ab}$ & $8.94 \mathrm{ab}$ \\
\hline H2 (0.4 ml/L air) & $15.36 \mathrm{a}$ & $0.60 \mathrm{a}$ & $10.37 \mathrm{a}$ \\
\hline H3 (0.8 ml/L air) & & & \\
\hline
\end{tabular}

Keterangan :Notasi huruf dan kolom yang sama berbeda tidak nyata taraf $5 \%$. 
Tetapi dibandingkan dengan $\mathrm{H} 1$ (0.2 ml/1 air pupuk cair hayati) dengan penghasilan 12.25 umbi/sampel menunjukkan perbedaan nyata $(\mathrm{p}>0.05)$ terhadap $\mathrm{H} 3$, tetapi tidak berbeda terhadap $\mathrm{H} 2$. Manakala tanpa pupuk $(\mathrm{Ho}=$ tanpa pupuk) merupakan penghasilan jumlah umbi paling rendah dengan rata-rata 11.78 umbi/sampel, tetapi tidak berbeda nyata terhada penggunaan pupuk dengan dosis rendah $(\mathrm{H} 2)$.

\section{Berat Umbi/sampel (g)}

Hasil penimbangan masingmasing perlakuan dengan pengujian ukuran benih dan dosis pupuk cair hayati tanaman kentang(Tabel3).

Tabel 3. Hasil analisa berat umbi/sampel dari pengaruh ukuran bibit terdapat ukuran bibi paling

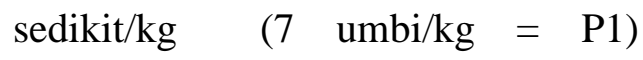
memberikan penghasilan produksi paling besar dengan rata-rata 0.58 $\mathrm{kg} / \mathrm{sampel}$, tetapi dengan bibit ukuran 14 umbi/kg (P2) rata-rata $0.55 \mathrm{~kg} / \mathrm{sampel}$ berbeda tidak nyata sedangkan P3 memberikan pengaruh yang tidak nyata terhadap P1. P3bibit dengan 21 umbi/kg (P3) produksi paling rendah rata-rata 0.53 $\mathrm{kg} / \mathrm{sampel}$ berbeda nyata terhadap P1.

Pupuk cair hayati dosis paling tinggi $0.8 \mathrm{ml} / \mathrm{l}$ air (H3) memberikan produksi/sampel paling $\begin{array}{lll}\text { tinggi rata-rata } & 0.60\end{array}$ $\mathrm{kg} /$ sampel.Dibandingkan dengan dosis $0.4 \mathrm{ml} / \mathrm{l}$ air (H2) menghasilkan rata-rata $0.56 \mathrm{~kg} / \mathrm{sampel}$, dimana keduanya menunjukkan perbedaan tidak nyata $(\mathrm{p}<0.05)$. Penggunaan dosis rendah pada dosis $0.2 \mathrm{ml} / \mathrm{l}$ air (H1) dengan produksi rata-rata 0.54 $\mathrm{kg} /$ sampel berbeda nyata berbanding H3, tetapi tidak berbeda terhadap perlakuan H2. Tanpa penggunaan pupuk (control $=$ Ho) merupakan penghasilan umbi kentang yang paling rendah $(0.52 \mathrm{~kg} / \mathrm{sampel}$ berbeda nyata terhadap $\mathrm{H} 2$, dan $\mathrm{H} 3$.

\section{Berat umbi/plot (kg)}

Produksi kentang (kg/plot) hasil penimbangan dari pengaruh ukuran bibit kentang dan penggunaan beberapa dosis pupuk cair hayati yang dilakukan setelah dipanen meberikan pengaruh yang berbeda nyata (Tabel 3).

Tabel 3. Dapat diketahui bahwa pengujian ukuran bibit 
terhadap produksi dengan ukuran bibit 7 umbi/kg (P1) merupakan bibit paling besar diperoleh hasilpaling tinggi rata-rata 9.58 kg/plot). P1 tidak memberikan pengaruh yang nyata dengan penggunaan ukuran bibit 14 umbi/kg (P2) dengan rata-rata $8.08 \mathrm{~kg} / \mathrm{plot}$. Perlakuan P1 (21 umbi/kg (P3) dengan hasil rata-rata $6.97 \mathrm{~kg} / \mathrm{plot}$, merupakan hasil paling rendah dengan berbeda tidak nyata terhadap $\mathrm{P} 2$, tetapi berbeda nyata terhadap P1

Dengan semakin kecilnya ukuran bibit kentang memberikan produksi yang semakin rendah, berdasarkan analisa diperoleh korelasi dengan regresi persamaan regresi dengan $\hat{Y}=0.186 \mathrm{P}+10.81$ dan $\mathrm{r}=0.98$ seperti yang terlihat pada Gambar 2.

Tabel 3.Diketahui pupuk cair hayati berperan dalam peningkatan terhadap produksi.Perbedaan yang nyata terlihat pada penggunaan dosis tinggi pupuk cair hayati pada $0.8 \mathrm{ml} / \mathrm{l}$ air (H3) dapat menghasilkan produksi paling tinggi rata-rata 10.37 $\mathrm{kg} /$ plot.H3 tidak berbeda nyata terhadap penggunaan dosis $0.4 \mathrm{ml} / \mathrm{l}$ air (H2) dengan rata-rata 8.94 $\mathrm{kg} /$ plot.H3 dibandingkan dengan pemberian dosis $0.2 \mathrm{ml} / \mathrm{l}$ air (H1) menunjukkan perbedaan yang nyata $(\mathrm{p}<0.01)$ dengan rata-rata 7.38 $\mathrm{kg} /$ plot. Tanpa penggunaan pupuk (kontrol) penghasil kentang paling rendah, namun tidak berbeda nyata dengan perlakuan pemupukan dosis $0.2 \mathrm{ml} / \mathrm{l}$ air (H1).

Berdasarkan peningkatan penggunaan dosis pupuk cair setara dengan peningkatan produksi (kg/plot), berdasarkan analisa diperoleh korelasi dengan persamaan linier dengan $\hat{\mathrm{Y}}=5.311 \mathrm{H}+6.35$ dan $r=0.97$ (Gambar 3). 


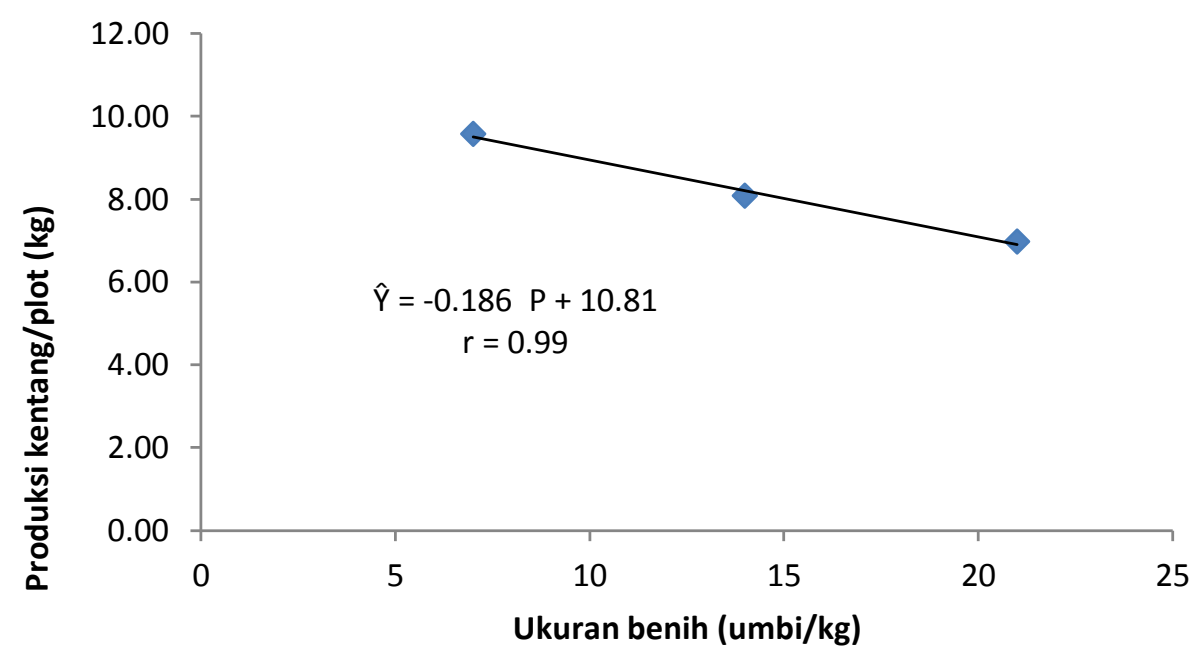

Gambar 2. Hubungan ukuran benih kentang terhadap produksi $(\mathrm{Kg} /$ plot $)$

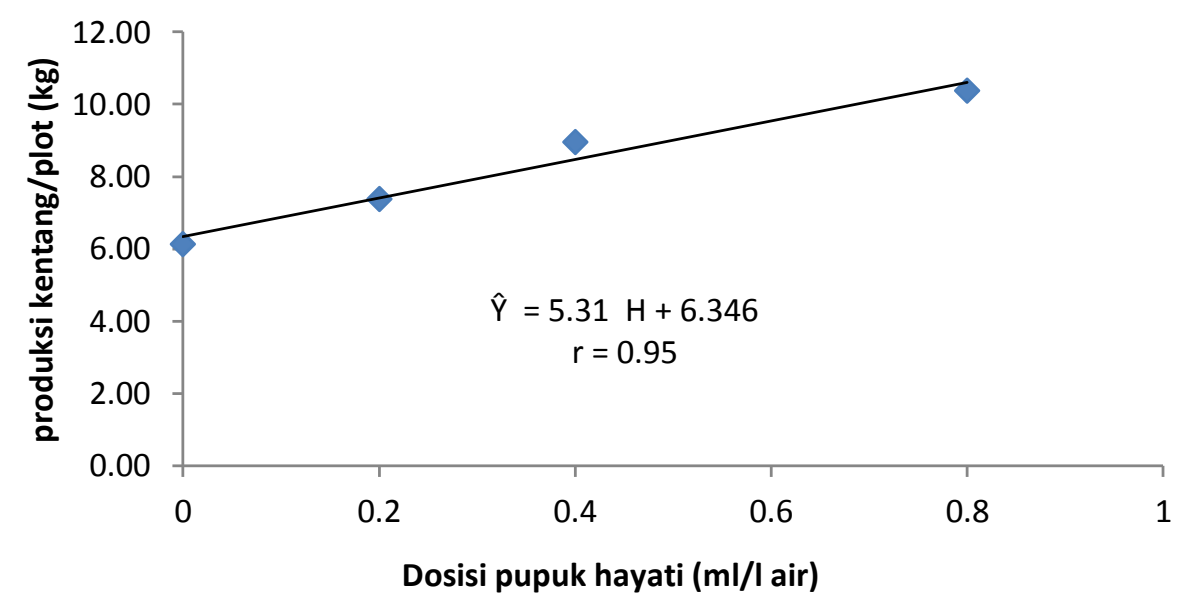

Gambar 3 . Hubungan penggunaan dosis pupuk hayati (ml/air terhadap produksi $\mathrm{kg} / \mathrm{plot}$

Pembahasan

Pengaruh Ukuran Umbi Bibit (G3) Terhadap Pertumbuhan dan Produksi Tanaman Kentang

Dari data pengamatan dan hasil analisis secara statistika maka diperoleh bahwa pengaruh perlakuan ukuran berat bibit berpengaruh nyata terhadap jumlah umbi per sampel (umbi), berat umbi per sampel (kg), berat umbi per plot $(\mathrm{kg})$, serta berpengaruh tidak nyata terhadap 
tinggi tanaman $(\mathrm{cm})$ dan jumlah cabang utama.

Pengaruh yang tidak nyata terhadap jumlah batang utama dan tinggi tanaman, namun perlakuan ukuran bibit memperlihatkan adanya peningkatan tinggi tanaman dan jumlah cabang utama dengan ukuran bibit yang digunakan semakin besar.Hal ini sesuai dengan hasil penelitian bibit berdasarkan berat terlihat semakin berat bibit yang dipakan maka menghasilkan tinggi tanaman dan jumlah cabang sebakin besar, namun tidak berbeda nyata (Bukit.A. 2008). Hal ini sesuai dengan Samadi (1997) yang menyatakan bibit kentang yang dianjurkan adalah $30-45 \mathrm{~g}$ atau 35 - $45 \mathrm{~mm}$ dan 40 - $60 \mathrm{~g}$ atau 45 - 55 $\mathrm{mm}$, menurut penelitian umbi yang berukuran besar akan menghasilkan jumlah tunas lebih banyak dibandingkan dengan yang berukuran lebih kecil. Hal ini didukung oleh Setiadi (2000) yang menyatakan umbi kentang untuk bibit dapat digunakan yang berukuran $30-45 \mathrm{~g}$ atau $50-60 \mathrm{~g}$. Kalau besarnya diukur rata - rata antara $30-35 \mathrm{~mm}$ atau $45-50 \mathrm{~mm}$ dan konon yang bagus $55 \mathrm{~mm}$.
Jumlah mata tunas sekitar 35. dan didukung juga oleh Soelarso (1997) yang menyatakan mata umbi kentang sebenarnya adalah buku dari batang. Jumlah mata umbi $2-14$ buah tergantung pada ukuran umbi yang digunakan.

Pengaruh nyata terhadap berat umbi persampel, berat umbi per plot dan produksi per hektar disebabkan oleh semakin banyak mata tunas, maka stolon yang terbentuk semakin banyak, dengan meningkatnya jumlah stolon makaproduksi umbi akan semakin banyak. Hal ini sesuai Sutopo (1988) yangmenyatakan dengan semakin besar umbi bibit maka kandungan proteinnya makinbanyak pula.Besar benih berpengaruh terhadap kecepatan pertumbuhan danproduksi, karena berat bibit menentukan besarnya kecambah pada saat permulaandan berat tanaman pada saat dipanen(Bukit.A. 2008).

Jumlah umbi per plot berpengaruh nyata disebabkan oleh semakin banyakmata tunas, maka semakin banyak batang tanaman sehingga menghasilkan banyakumbi. Selain itu kandungan unsur hara yang ada di dalam tanah dapat di 
serapoleh tanaman. Hal ini didukung oleh Setiadi (2000) yang menyatakan untukmenentukan umbi untuk bibit tergantung dari diri sendiri, menurut petani umbiyang baik untuk bibit adalah yang sehat, berukuran besar mempunyai mata tunas $3-5$ dan bobotnya $80-100$ g. (Bukit. 2008).

Pada persentase jumlah kelas umbi A, B, C dan D berpengaruh nyata hal inidisebabkan karena ukuran berat umbi yang digunakan menentukan banyaknyatunas yang dihasilkan. Tunas yang berkembang menjadi batang utamamenghasilkan jumlah dan besar umbi. Semakin besar ukuran umbi maka jumlahbatang utama semakin banyak dan jumlah umbi yang di hasilkan akan semakinbanyak pula dengan ukuran yang semakin kecil. Hal ini didukung olehSoelarso (1997) yang menyatakan penggunaan umbi bibit ukuran besar (60 g)akan menghasilkan umbi kentang ukuran kecil (20-50 g). Tunas yang banyak akanmenghasilkan ukuran umbi yang relatif kecil-kecil. Sedangkan tunas yang sedikitakan menghasilkan ukuran umbi relatif besar (Bukit. A. 2008).
Setiadi (2000) menyatakan bahwa salah satu faktor pembatas dalampertumbuhan dan perkembangan tanaman adalah penyerapan zat hara yangpenting (esensial). Dalam proses pertumbuhan tanaman menyerap unsur harasehingga terjadi proses metabolisme antara lain pertumbuhan sel dipenuhi,disamping itu melalui berat umbi berarti ketersediaan makanan untukpertumbuhan semakin meningkat.

\section{Pengaruh Dosis Pupuk Cair} Hayati Terhadap Pertumbuhan dan Produksi Tanaman Kentang.

Berdasarkan data yang telah dihasilkan padapengamatan pada seluruh parameter yang diamati pada tanaman kentang dapat dikaitkan bahwa pengaruh pemberian beberapa tingkat dosis pupuk cair hayati. Hal ini terlihat bahwa dosis pupuk cair hayati member pengaruh yang berbeda nyata terhadap tinggi tanaman, jumlah umbi sampel, berat umbi per sampel, jumlah umbi per plot, berat umbi per plot dan persentase produksi. Pemberian pupuk cair hayati merupakan salah satu faktor dalam meningkatkan 
pertumbuhan tanaman dan peningkatan produksi. Pemberian pupuk merupakan pensuply zat hara penting yang diperlukan tanaman. Ketersediaan unsur hara dapatditingkatkan kepada perkembangan sepanjang pertanaman dan produksi yang dihasilkan adanya respon dengan meningkatkanpemberian dosis pupuk hayati. Rendahnya tingkat pemberian unsur hara pada tanaman akan mengakibatkan terhambatnya pertumbuhan danperkembangan tanaman sekali gus menurunkan tingkat produksi kentang khususnya dibandingkan dengan dengan dosis pupuk yang lebih tinggi. Novizan (2002) menyatakan bahwa bila tanaman mengalami kakurangan unsur akan mengakibatkan pembentukan umbi terhambat atau tidak berumbi sama sekali. Sutedjo (2002). Hal ini dapat diketahui bahwapenggunaan pupuk sebagai salah satu usaha untuk meningkatkan produksi kentang sudah sangat membudidaya, dan para petani telah menganggap bahwa pupuk dan cara pemupukan sebagai salah satu hal yang tidak dapat dipisahkan dalam kegiatan usaha taninya (Anonim,2007). Berdasarkan dosis yang semakin tinggi diberikan pada tanaman merupakan ketersediaan unsur pada pertumbuhan, hal ini sesuai dengan pendapat Sutedjo (2002) menyatakan kebutuhan unsur hara untuk tiap fase pertumbuhan tanaman berbeda- beda (Foth, 1991; Hakim, dkk 1986).

Pupuk cair Hayati merupakan dari jenisTiens Golden Harves adalah suatu teknologi penyubur tanah untuk tanamanyang diperbuat dengan teknologi Agricultural Growth Promoting Inoculant (AGPI) yang terdiri dari campuraninoculun, hormon tubuh dan mikroba tanah.Komponen mikroorganisme yang terdapat dalam pupuk cair hayati ini sangat diperlukan dalam meningkatkan kesuburan tanah secara biologis. Mikroorganisme yang yang terkandung antara lainAzospirillium sp., Azobacter sp., mikroba pelarut P. Laktobacillus sp., dan mikroba pendegrasi selulosa. Selain dari pada mikroorganisme dalam pupuk hayati ini juga mengandungi unsur mikro yang tinggi seperti : $\mathrm{P}=34,70 \mathrm{ppm} ; \mathrm{K}=$ 1.700 ppm; $\mathrm{C}$ organic $=0,92 \% ; \mathrm{N}=$ $0,04 \% ; \mathrm{Fe}=44,3 \mathrm{ppm} ; \mathrm{Mn}=0,23$ ppm; $\mathrm{Cu}=0,85$ ppm; $\mathrm{Zn}=3,7$ ppm. 
Unsur ini sangat diperlukan bagi tanaman untuk pertumbuhan dan produksi.(Lingga dan Marsono. 2004).

Pupuk cair hayati berperan sebagai meningkatkan hasil pertanian organik secara berkesinambungan.penyubur bio organik multiguna yang mangandung mikroorganisme (bakteri dan jamur) yang diproses secara sempurna dengan berbagai bahan alami yang berperan dalam pengikatan unsur hara penting bagi tanaman dan berperan meningkatkan kesuburan tanah (Novizan. 2002). Pupuk cair hayati juga mengandung nutrisi, senyawa bioaktif, hormon pertumbuhan, anti hama maupun vitamin serta diperkaya dengan hara esensial seimbang bagi tanaman, bertahan dalam waktu lama' mengandung minimal 6 spesies mikroorganisme unggul untuk mengikat dan meningkatkan unsur hara penting bagi tanaman (Anonim, 2010).

Pengaruh Interaksi Antara Ukuran Umbi Bibit Dengan Dosis Pupuk Cair Hayati Terhadap

\section{Pertumbuhan dan Produksi}

Tanaman Kentang.

Berdasarkan hasil sidik
ragam menunjukkan bahwa hasil tidak ada interaksi yang berbeda nyata antaraperlakuan ukuran umbi bibit dengan dosis pupuk cair hayati pada semua parameter yang diamati.Keadaan ini disebabkan karena pembentukan akar pada tanamankentang didukung oleh unsur hara yang cukup pada tanaman, sehinggapembentukan umbi semakin banyak jika pupuk Cair Hayati semakin tinggi, diikuti dengan pertumbuhan dan produksi yang semakin besar. Hal ini sesuai dengan Sutopo (1988)yang menyatakan dengan semakin besar ukuran umbi bibit maka kandungan proteinnyamakin banyak pula.Ukuran benih berpengaruh terhadap kecepatan pertumbuhan dan produksi, karena berat bibit menentukan besarnya kecambah pada saat pertumbuhan dan berat tanaman pada saat dipanen (Foth, H. D. 1991; Hakim, N., dkk 1986).

Berdasarkan penelitian ini kedua factor yang diujikan tidak terdapat interaksi yang berbeda nyata akan tetapi hasil penelitian Bukit. A 
(2008) dengan menambahkan KCL pada ukuran bibit terdapat perbedaan yang nyata untuk parameter berat umbi per plot dan tinggi tanaman. Juga Marsono (2001) mengtakan bahwa kalium berperan dalam pertumbuhan dan perkembangantanaman kentang setelah umbi terbentuk. Tanaman yang cukup mendapat kaliumakan mampu membentuk umbi yang besar juga disebabkan oleh penyerapan airdan hara yang lebih baik.Juga Novizan (2002), menyatakan bahwa unsur kalium diperlukantanaman dalam sintesa protein dan karbohidrat serta translokasi karbohidrat lebihlancar.

Samadi (1997), menyatakan bahwa unsur kalium diperlukan tanaman untukpembentukan karbohidarat didalam umbi, untuk kekuatan daun, ketebalan daundan pembesaran daun tanaman.Poerwoidodo menyatakan bahwa bila salah satu faktor berpengaruhlebih kuat daripada faktor lainnya, maka pengaruh faktor tersebut tertutupi danbila masing - masing faktor mempunyai sifat yang jauh berbeda pengaruh dansifat kerjanya maka akan menghasilkan hubungan yang berpengaruh tidak nyatadalam mendukung suatu pertumbuhan tanaman.

Selanjutnya Hakim (1986), menyatakan bahwa pertumbuhan tanamanakan lebih baik bila faktor yang mempengaruhi pertumbuhan seimbang danmemberi keuntungan. Bila faktor ini tidak dapat dikendalikan maka pertumbuhanyang diharapkan tidak dapat diperoleh.

\section{KESIMPULAN DAN SARAN}

\section{Kesimpulan}

1. Penggunaan ukuran bibit G3 adalah 7 umbi/kg dan 14 umbi/kg adalah ukuran bibit menghasilkan produksi yang paling tinggi untuk penanaman tanaman kentang dilapangan.

2. Pemberian pupuk hijau pada dosis $0.4 \quad \mathrm{ml} / \mathrm{l}$ air $(\mathrm{H} 2)$ merupakan dosis pupuk yang dianjurkan dalam penanaman kentang.

3. Interaksi jumlah umbi/kg engan dosis pupuk hijau cair Hayati tidakmemberi pengaruh yang nyata 
terhadap semua parameter yang diujikan.

\section{Saran}

Penelitian ini menggunakan ukuran umbi kentang 7 umbi/kg G3 dan penggunaan dosis pupuk hijau 0.4 $\mathrm{ml} / \mathrm{l}$ air memberikan pengaruh terhadap pertumbuhan dan Produksi. Perlu dilakukan penelitian lebih lanjut dengan pupuk hijau lainnya dan jumlah umbi kentang/kg sebagai bibit kentang

\section{DAFTAR PUSTAKA}

Allard, W.R., 1960.Principel of Plant Breeding. W. John and Sons, inc, Colorodo State Univwesity.

Anonimous, 2006. Tanaman Kentang. http://www.

Warintek.Bantul.ge.id.

Anonimous, 2009. Pupuk Hayati. Produk Ultramic (http://www.pupuk hayati.Co.id

Anonimous. 2010. Pemupukan dengan Pupuk Hayati (http://www. Kuniapress.com.

$$
\text { Deptan Ci No }
$$
474/Hayati/Deptan-PPI/I/2010.

Asandhi,A.A.1985.Petunjuk Praktis Bercocok Tanam Kentang Dataran Medium.

Balai Penelitian Hortikultura Lembang. Lembang
Bukit A. 2008. Pengaruh besar berat umbi Bibit dan Dosis pupuk $\mathrm{KCl}$ Terhadap Pertumbuhan danProduksi Kentang (Solanum tuberosum L). Tesis UniversitasSumatera Utara (USU) Medan.

Foth, H. D. 1991. Dasar Dasar Ilmu Tanah. Gadjah Mada University Press, Yokyakarta. Hal 361 dan 368.

Gardner, F. P., R. B. Pearce, dan R. L. 1991. Fisiologi Tanaman Budidaya. UI Press. Jakarta. Terjemahan Susilo H. Hal 155 dan 269.

Hakim, N., dkk 1986.Dasardasar Ilmu Tanah. Universitas Lampung Press, Lampung.

Harjadi. 1988, Pengantar Agronomi, P. T. Gramedia, Jakarta

Hartus, T. 2001, Usaha Pembibitan Kentang Bebas Virus, Penebar Swadaya, Jakarta.

Lingga, P. dan Marsono. 2004. Petunjuk Penggunaan Pupuk. Penebar Swadaya, Jakarta

Novizan.2002. Petunjuk Pemupukan yang Efektif. Agromedia Pustaka, Jakarta.

Nyakpa, M.Y., A.M. Lubis., Pulung., A.G. Amrah., A. Munawar., G.B. Hong., dan

N. Hakim., 1988. Kesuburan Tanah. UNILA, Lampung.

Rubatzky, V.E dan M. Yamaguchi., 1996. Sayuran Dunia 2. Prinsip, Produksi dan gizi. ITB Press, Bandung. 
Nainggolan P. dan D. Tarigan. 1992. Pengaruh Sumber dan Dosis Pupuk Kalium

Terhadap Hasil dan Mutu Umbi Kentang.Dalam : Jurnal Hortikultura 2.

Balitbang Pertanian, Pusat Penelitian dan Pengembangan Hortikultura.Hal 781-787. Jakarta.

Poerwowidodo. 1992. Telaah Kesuburan Tanah. Angkasa, Bandung

Purohit,S.S, 1986.Hormonal Regulation of Plant Growth and Development. Volume 3

Agro Botanical Publisher http://www.OVPg.org/98otrios.htm . India.

Rukmana, R. 2002. Usaha Tani Kentang di Dataran Medium. Kanisius, Yoyakarta.

Samadi, B.1997. Usaha Tani Kentang, Kanisius, Yogyakarta.

Setiadi dan Surya Fittri N, 2000, Kentang dan Pembudidayaan, Penebar Swadaya,Jakarta.

Sharma,O.P.,2002.Plant

Taxonomy. Mc Graw- Hill Company Limited .New Delhi

Soelarso, B.R, 1997. Budi Daya Kentang Bebas Penyakit, Kanisius, Yogyakarta.

Sunarjono H,1978, Budi Daya Kentang (Solanum tuberosum L), P.T. Soeroengan,Jl. Pecenongan, Jakarta.

Sutedjo, M.M., 2002. Pupuk Dan Cara Pemupukan. Rineka Cipta. Jakarta
Sutopo., L., 1988, Teknologi

Benih, CV. Rajawali Jakarta.

Thompson andKelly., 1957.Vegetable Crops. McGraw-hill Publications in the

Agricultura Sciences, New York Toronton London. 